\title{
Seeking cancer treatment for their children: experience of parents from areas distant from Lima-Peru
}

\author{
Buscando tratamiento oncológico para sus niños: experiencia de \\ padres procedentes de zonas distantes a Lima-Perú \\ Procurando tratamento oncológico para seus filhos: experiências \\ de pais de zonas distantes de Lima-Peru
}

\section{Gladys Carmela Santos Falcón ${ }^{a}$ Lili Ana Ordoñez Espinozaa,b María del Carmen Velandres Siles ${ }^{c}$ Roberto Zegarra Chapoñan ${ }^{\mathrm{d}, \mathrm{e}}$ Jhon Alex Zeladita Huamana,d}

How to cite this article: Santos Falcón GC, Ordoñez Espinoza LA, Velandres Siles MC, Zegarra Chapoñan R, Zeladita Huaman JA. Seeking cancer treatment for their children experience of parents from areas distant from Lima-Peru. Rev Gaúcha Enferm. 2021:42:e20200323. doi: https://doi. org/10.1590/1983-1447.2021.20200323
- Universidad Nacional Mayor de San Marcos (UNMSM), Facultad de Medicina, Departamento Académico de Enfermería. Lima, Perú.

${ }^{-}$Instituto Nacional de Enfermedades Neoplásicas (INEN). Lima, Perú.

c Asociación de Voluntarias por los Niños con Cáncer, Casa Albergue Teresa Pasco Ramiréz. Lima, Perú.

${ }^{-}$Universidad María Auxiliadora (UMA), Facultad de Ciencia de la Salud. Lima, Perú.

eMinisterio de Salud (MINSA), Escuela Nacional de Salud Pública. Lima, Perú.

\section{ABSTRACT}

Objective: To understand the experiences of parents of children with cancer who come from areas distant from Lima-Peru during the search for cancer treatment for their children.

Method: A descriptive-exploratory qualitative approach study. Focus groups and semi-structured interviews were carried out. The sample consisted of 18 parents who come from remote areas from Lima who attended specialized hospitals. The qualitative analysis was of thematic content, proposed by Minayo.

Results: Three categories emerged: Accessing cancer care in Lima hospitals; Having diverse personal experiences during their child's treatment; and Reporting the socioeconomic and labor impact during their stay in Lima.

Final considerations: Understanding these experiences could help health professionals to implement strategies of socioeconomic support to facilitate access to health services for children with cancer. Hospitals must guarantee the satisfaction of the basic needs of parents.

Keywords: Child. Neoplasms. Parents. Health services accessibility.

\section{RESUMEN}

Objetivo: Comprender las experiencias de los padres de niños con cáncer que proceden de zonas distantes a Lima-Perú durante la búsqueda del tratamiento oncológico de sus hijos.

Método: Estudio de enfoque cualitativo tipo descriptivo-exploratorio. Se realizó grupos focales y entrevistas semiestructuradas. La muestra estuvo constituida por 18 padres provenientes de zonas alejadas a Lima que acudieron a hospitales especializados. El análisis cualitativo fue de contenido temático, propuesto por Minayo.

Resultados: Emergieron tres categorías: Accediendo a atención oncológica en los hospitales de Lima; Teniendo diversas experiencias personales durante el tratamiento de su niño; y Relatando el impacto socioeconómico y laboral durante su permanencia en Lima.

Consideraciones finales: Comprender estas experiencias podría ayudar a los profesionales de la salud a implementar estrategias de soporte socioeconómico para facilitar el acceso de los niños con cáncer a los servicios de salud. Los hospitales deben garantizar la satisfacción de necesidades básicas de los padres.

Palabras clave: Niño. Neoplasias. Padres. Accesibilidad a los servicios de salud.

\section{RESUMO}

Objetivo: Compreender as experiências de pais de crianças com câncer provenientes de áreas distantes de Lima, Peru, durante a busca pelo tratamento oncológico de seus filhos.

Método: Estudo de abordagem qualitativa, do tipo descritivo-exploratório. Grupos focais e entrevistas semiestruturadas foram realizadas. A amostra foi composta por 18 pais de áreas remotas que foram a hospitais e a análise foi do tipo temático proposto por Minayo.

Resultados: Surgiram três categorias: Acesso ao tratamento do câncer nos hospitais de Lima; Tendo diversas experiências pessoais durante o tratamento do filho; e Relatando o impacto socioeconômico e trabalhista durante a estadia em Lima.

Considerações finais: 0 entendimento dessas experiências poderia ajudar aos profissionais de saúde a implementar estratégias de apoio socioeconômico para facilitar o acesso de crianças com câncer aos serviços de saúde. Os hospitais devem garantir a satisfação das necessidades básicas dos pais.

Palavras-chave: Criança. Neoplasias. Pais. Acesso aos serviços de saúde. 


\section{INTRODUCTION}

Cancer is a public health problem that affects children and adolescents. Globally, it is estimated that the incidence of pediatric cancer for the year 2019 was 397,000 cases $^{(1)}$. Furthermore, the success of cancer treatment in children and adolescents varies according to the degree of economic development, while in countries with higher income, around $80 \%$ are cured; Aversely, in low- and middle-income countries, approximately $20 \%$ are cured $^{(2)}$.

On the other hand, considering that cancer mortality is associated with multiple social factors such as living in rural $\operatorname{areas}^{(3)}$, in order to reduce the death of children from cancer, mainly in more vulnerable populations, it is essential to understand how experiences and perceptions influence in access to health care.

Likewise, families living in distant geographic areas face cultural, economic, social and religious barriers to access the timely diagnosis and treatment of childhood cancer ${ }^{(4)}$. Especially in Peru, where hospitals specialized in pediatric oncology are located in the capital of the country, 18.4\% of children with cancer abandoned their treatment and living in areas far from Lima was reported as a factor associated with abandonment of the cancer treatment ${ }^{(5)}$. In the year 2016, malignant neoplasms were the second cause of mortality, surpassed only by mortality from infectious and parasitic diseases; and it is estimated that 365,387 years of healthy life were lost, which represents $6.9 \%$ of the disease burden in Peru(6).

Therefore, in the analysis of access to health services for children with cancer, not only aspects related to health facilities should be considered, but also the experiences, and perceptions of parents. Even more so if it is taken into account that access to health services is "the opportunity to reach and obtain adequate medical care services in situations of perceived need", in which interact the characteristics of the people, the social environment and the health system ${ }^{(7)}$.

This problematic was addressed through qualitative research. A recent study conducted in India highlights that caregivers from remote areas face challenges in finding their way around hospitals and finding accommodation ${ }^{(4)}$. Likewise in Ghana, another study determined that the decision-making of parents of children with cancer to seek health care is influenced by various social determinants and individual experiences ${ }^{(8)}$.

Mainly, studies that address the experiences of caregivers of children with cancer report that they experience negative feelings such as fear, uncertainty and anguish ${ }^{(9)}$, they highlight the economic impact of the disease ${ }^{(10)}$; and experiences as barriers to access specialized care ${ }^{(8)}$; however, few studies have deepened into the experiences of parents of children with cancer during diagnosis and treatment in hospitals distant from their home of origin ${ }^{(4,11)}$, in which they face challenging situations that will determine the survival of their children and continuity of treatment.

In Peru, families of children with cancer do not have hospitals that provide cancer treatment in their place of origin, so they move to the capital city of Lima to access specialized care; taking into account this situation little addressed in the literature, the question that guided the research was: What were the experiences of parents who come from distant areas during the search for cancer care for their children in specialized hospitals in Lima? In this sense, the objective of the study was to understand the experiences of parents of children with cancer who come from areas distant from Lima-Peru, during the search for cancer treatment for their children.

\section{METHOD}

This study was of qualitative descriptive-exploratory approach, through which the living experience of parents who belong to a particular group in a certain social context was addressed, to record, analyze and interpret the information, thus allowing the generation of new knowledge ${ }^{(12)}$.

The research was carried out during the months of October to December 2019, in three hospitals that diagnose and provide cancer treatment to children with cancer located in Lima-Peru. The National Institute of Neoplastic Diseases (Instituto Nacional de Enfermedades Neoplásicas - INEN), which belongs to the Ministry of Health (Ministerio de Salud - MINSA), the Hospital Nacional Edgardo Rebagliati Martins and the Hospital Nacional Guillermo Almenara Irigoyen; the latter belong to the Social Health Insurance (Seguro Social de Salud - ESSALUD).

The Peruvian health system is mixed and segmented, characterized by the fact that there are private health establishments such as clinics and public health establishments that belong to the MINSA and others that belong to the Ministry of Labor and Employment Promotion (Ministerio del Trabajo y Promoción del Empleo), such as the EsSALUD hospitals. Children with cancer, whose parents participated in the study, were cared for in public hospitals and were affiliated with either the EsSALUD insurance or the Comprehensive Health Insurance (Seguro Integral de Salud - SIS) provided by MINSA. However, there are sociocultural and economic differences in the insured, while those affiliated to the ESSALUD insurance have greater purchasing power and some job stability; people affiliated to the SIS have greater financial problems, most receive a remuneration equivalent 
to the minimum vital income [265 dollars] and others carry out temporary jobs, without fixed remuneration.

The selection of parents was made through non-probabilistic sampling for convenience according to the availability of participation. The identification of them was carried out after coordination with the health personnel of the hospitals and review of the clinical history. Parents over 18 years old who come from distant areas of Lima and whose children were diagnosed with cancer were included in the study; and those who reported not having time available or that their children required more supervision because they presented adverse reactions to chemotherapy were excluded. The sample consisted of 18 parents that was established when reaching the saturation level.

In hospital environments, free of noise and interference provided by health personnel, semi-structured interviews were conducted with parents in order to explore their experiences, which lasted from 35 to 40 minutes. The questions that guided the interview were: 1 . How was your experience in the Lima hospital during the diagnosis and treatment of your child with cancer? 2. Tell me about the conditions of your food, accommodation and other basic needs during your stay in Lima. 3. What consequences did your transfer to a hospital in Lima have for your family for the treatment of your child?

After the analysis of the information obtained from the interviews, in order to deepen the data, a focus group guide was structured. Two focus group sessions were held with some participants who had been interviewed and other parents, in the shelters where they resided due to the ease of access, and which had a suitable environment to perform this technique. The sessions lasted approximately two hours, were recorded with the consent of the participants, and then transcribed. This analyzed information was incorporated into the categories that emerged with data from the interviews, which allowed obtaining more reliable results about the parents' experiences during the treatment of their children.

The thematic content analysis was carried out, which comprises three stages: 1) pre-analysis, which comprises fluctuating reading, and corpus construction; 2) exploration of the material comprising cutting the text into record units, coding and classifying the data into categories and subcategories; 3) treatment of the results obtained and interpretation of the data ${ }^{(12)}$.

The methodological and ethical aspects were reviewed by the Ethics Committee of the Universidad María Auxiliadora of Lima Peru and were approved by the Certificate No. 02-2019. Before the interview, all participants signed the informed consent, after detailed information on the objectives, purpose, and process of the study. The anonymity of the participants was guaranteed by assigning to each of them the names of the most prominent Peruvian heroes and heroines. Those investigated were quite open and interested in reporting their experiences.

\section{RESULTS}

18 parents from 15 regions of Peru were interviewed. In relation to the distance in kilometers $(\mathrm{Km})$ that they traveled from their place of origin to Lima, during the search for cancer care, the shortest distance was $303 \mathrm{Km}$ (from the Ica region) and the longest distance was $1012 \mathrm{Km}$ (from the lquitos region). Regarding their socioeconomic situation, the average monthly family income of the people interviewed was 400 soles [119.76 dollars]. For the care of their child with cancer, 8 interviewees went to INEN and 10 to EsSALUD hospitals. The female sex was predominant (14 of 18). The minimum age of the interviewees was 22 years and the maximum age was 53 years.

From the analysis of the parents'statements, three categories emerged:

Category 1. Accessing cancer care in Lima hospitals: after the entire journey from their region of origin, upon arrival in Lima, during the specialized care, two subcategories emerged:

Receiving good care from the health personnel in the hospitals: the parents received support, guidance and good treatment from the health personnel during the hospitalization of their children; in addition, they considered that health personnel are trained to adequately care for them. They also stated that they joined their purpose and strengthened their spirituality:

Very well, both with nurses, doctors and even the cleaning girls, everything has been ok [...] there is no complaint, they guide us. There are nurses who encourage you, give you encouragement, tell you that everything is fine, you have to continue and join the fight; and above all with the help of God, together we will win (Rosa Merino).

The doctors, nurses and technicians, only in that ward, have been good people, that is, I think they are trained to care (Clorinda Matto).

Perceiving negative attitudes and reactions from health personnel: some parents during access to cancer care pointed out differences in the treatment of health personnel, while during their first contact with the health system (emergency services) they reported that the personnel were 
hostile and not allowed to participate in the care; mainly, because they prioritized compliance with institutional norms, such as restraint measures, without considering the clinical condition of the children. Later in the oncology services they received a friendly and warm treatment:

In the specialty hospital, the treatment is nice there [...] at leastyou're next to your patient. In another hospital that I arrived first, it is different; when I arrived, it was a change forme and my daughter [...] they have the children alone, and since they try to take off the tracks, they tie them from feet to hands [...] the parents wait outside the emergency seated, they don't let us in (María Rostwowroski).

The interviewees report that some nurses are not very tolerant with the children and that some physicians during their care did not have time to guide them about the disease, duration and complications of treatment:

Some graduates (nurses) lose patience; I think there should be talks, communicating to mothers, more information about this disease. I didn't even know that they were platelets (José Baquíjano).

But when I came, the doctor who treated me was fleeting, she told me now she doesn't have time [...] not all the staff are so friendly nor are all the doctors that good (María Parado).

Likewise, the parents during the care process felt misunderstood by the administrative staff in their demand to comply with the bureaucratic procedures, without considering their condition and also reported having been mistreated by the hospital security personnel:

Well, I would give the hospital a 9 (out of 10), if there were not those administrative staff that make us suffer as mothers and people, who come from the provinces (Rosa Merino).

The guard threw us out, he did not want me to leave my stuff in the emergency [...] because we are foreigners from the provinces and I had nowhere to leave my stuff (José Baquíjano).

Category 2: Having diverse personal experiences during their child's treatment: among the parents' personal experiences, two subcategories emerged:

Considering it very difficult to stay in Lima without relatives: The parents found it necessary to travel due to the deterioration of their son's health in search for specialized care; they consider that it was very difficult to arrive and stay in Lima without relatives to turn, they emphasize that they never thought to know it in these circumstances. Some parents who were unaware of the shelters, reported facing difficult situations such as spending the night in the hospital institution; one of the mothers even reported that she remained in the hospital throughout her son's treatment:

Well, it was hard, very difficult to get here, a city that I had never arrived in my life and I did not even imagine arriving, I only heard about Lima and that it was nice, but not to arrive in this situation in which I am here with my son sick [...] there are no relatives here and we had to be there (hospital), until we were discharged and able to return (Túpac Amaru).

I don't go out, no, because I practically sleep here and my daughter there, that is, one is like interned with her (Blanca Varela).

Accessing support networks: shelters, friends and family support: most parents accessed support networks such as shelters where they received support in meeting their basic needs (accommodation, food and hygiene); consider that this support contributed to their child's recovery and promoted socialization:

Practically, here (Shelter) we have everything, there is food for everyone, a bed to sleep in, a place to bathe, it is like our house (Juana de Dios).

There are workshops for children, they do not feel alone, they can sharesomething, they can play. (Clorinda Matto).

On the other hand, while staying in some shelters that do not have adequate infrastructure, they were separated from their children and shared common bathrooms, which caused privacy problems. In addition, they perceived that the established norms were very strict, they did not consider the health status of their children by imposing the norms of coexistence, schedules and rigid permits that violated the tranquility of the parents. This situation caused some of them to leave the shelters to live with friends or acquaintances or simply rent a lodging, which generated greater financial toxicity for the family:

I slept apart, separated from my daughter who was in treatment (because the shelter does not allow father and daughter to be in the sameroom), the chemo, it shocked her a lot and I could not be with her, [...] It is difficult to bear and share with people you don't know, you had to 
change in front of everyone, we would queue to go to the bathroom. (José Baquíjano).

We were surprised at the shelter by the activities assigned to me and my pregnant daughter (mother of the sick child), I did not agree to send me to clean everything (Lucha Reyes).

There are rules that you must follow, I think it's okay, I just couldn't follow because I was taking care of my little son (José Olaya).

The parents investigated receive support from their relatives (from their places of origin), however, at any time they can present expenses that demand the treatment of their children and as they do not have enough money, in some cases they are forced to go into debt, seeking the recovery of their child's health:

There has been a brutal change in our life and we are getting comfortable. My son got sick and then we had financial problems and it got complicated for us; and now my family is also doing activities so they can send us money to pay for our stay (Chabuca Granda).

So, very apart from having the problem of the disease, you have to have money for any emergency since sometimes the insurance does not have that, so what do we do? What do we have left? get into debt then (Blanca Varela).

Category 3: Reporting the socioeconomic and labor impact during their stay in Lima: among the various problems that the parents had, three subcategories emerged:

Referring to family and labor problems due to staying in Lima: the parents stated that because they remained accompanying their son in the capital during his treatment, they left all their activities, their jobs, their studies and were also forced to entrust the care of their other minor children their relatives in their areas of origin and others who work were forced to request work permits charged to replace these hours:

It was the biggest pain (Crying), both for me and for my son who is 4 years old (who stayed in his hometown), sincelleft him with his grandparents because he does not have his father, and he (son) claimed me (María Parado). Istopped studying, lleft everything (María Rostwowroski). I came on vacation, but the vacation period is over, I already have 15 days practically with an obligation to replace it (overtime) (Juan Vizcardo).
They also mentioned that, as a result of the transfer and treatment of their son in Lima, in many cases their older daughters, due to financial problems, stopped studying and took care of their siblings; other minor children presented difficulties in their school performance:

My 18-year-old daughter stopped studying because now there is no one there (Arequipa). As a result of late payments that I have had and that I have not been able to pay; and that's why lasked my daughter to postpone her studies, even for 6 months (Juan Vizcardo).

This happened quickly, for my family it has been a bucket of cold water. I left my little daughter with my other daughter who stopped studying to help me at home (Clorinda Matto).

I have a son who has dropped his grades at school because I'm not there, you know that just as the father is the base, the mother is the complement of everything (Blanca Varela).

Facing economic problems generated by their stay in Lima and expenses for the treatment of their son: the parents indicate that they faced economic problems generated by their stay in Lima (food, transportation, and accommodation) and expenses for the treatment of their child; and to cover these expenses they had to provide their own resources or carry out activities to generate income:

I have had to left everything, work and a lot of things [...] and resort to (look for resources) making chicken (stew based on chicken for sale) because here you need to be able to support yourself (José Olaya).

I pay for the hotel myself, with my mother-in-law, we are trying to pay for ourselves in this way, in view of the fact that here in Lima it is expensive. We are already completing a month since we have been brought (Chabuca Granda).

In some hospitals, even though the children were affiliated with health insurance, the parents were required to process and pay for laboratory tests outside the hospital that these establishments did not perform. Additionally, they were asked to purchase some supplies such as lines for infusion pumps, which the children need for the continuity of their treatments; to these are added the mobility expenses necessary for the treatment of the minor in Lima, Peru. Situation that generates in some parents the need to borrow money, which produced anxiety and anguish: 
When we arrived, they sent me to take a blood test to see what type of leukemia it is and start treatment as soon as possible [...] that test costs 1100 soles [329.3 dollars] you have to lookformoney, lend yourself (Blanca Varela).

I have had to buy some lines for the infusion pump every time he receives his chemo (Juan Vizcardo).

\section{Neglecting their self-care to prioritize the treatment} and care of their child: the parents of the study neglected their self-care related to food, rest, and other expenses on their person; for prioritizing the expenses generated by the treatment and purchase of complementary food for their child during hospitalization. Therefore, they request greater financial support from the government to cover their travel expenses and stay in Lima because in addition to their sick child they have other children who are in their place of origin:

\begin{abstract}
Mothers sometimes, because of so many worries, because of so many things that happen, we do not eat as we should, and also because of the money factor, because things are expensive, because their diet (of their son), their milk, their fruits, everything that have to give them they arestrong, we have strong expenses (Rosa Merino).
\end{abstract}

It is important to note that the parents could not go to restaurants due to financial problems. In some cases, they ate what their children left behind or were sometimes forced to request food from the pastry staff. In addition, since they did not have a place to rest, they did so on the hospital benches or stretchers; only one of the interviewees mentioned that she was staying in a hotel, but for the majority it was expensive:

Well, more than anything else, the need is economic, a menu here costs 8 soles [2.39 dollars], I eat what my daughter leaves behind, and when there is not enough, if I have money, I go out to buy" (Teresa Gonzáles). When my daughter was hospitalized, there were days when she did not eat; sometimes she would go to the basement (emergency dining room) to ask for food (Yma Sumac).

We slept on the benches, because my trip went from one moment to another, without bringing anything, just some blankets, nothing else (Juana de Dios).

Eventually, the parents had no information about the shelters, they slept on an emergency stretcher, even a grandmother reported that slept in the hospital with her daughter (mother of the sick girl) who had pregnancy complications; consider that they were practically hospitalized with their children:
During the 17 days that my daughter was hospitalized, they told me about shelters, but I did not know where or who to contact, I slept on the emergency stretcher, pulled cardboard, I had no family to go to (José Baquíjano).

I had no place to stay with my pregnant daughter (mother of the sick girl) since a hotel is charging between 70-90 soles (20.9 to 26.9 dollars), so, we stayed in the same hospital in emergency, my daughter with her tremendous belly stayed in the chair with her swollen feet (Cleofé Ramos).

It should also be noted that the parents alluded to the fact that the hospitals do not have hygienic services for companions, which is why they went to public toilets; in addition, for their hygiene, they found it necessary to find public toilets where to bathe and change clothes:

For us we have to look for, yesterday I went to bathe in the little square by Salaverry, a public bathroom I paid 3 soles [1 dollar], but I was going to take a cold shower, I had to wash, here (hospital) it is not possible (José Olaya).

Beyond all this odyssey lived by these parents, the important thing is to emphasize that they managed to get their children access to cancer diagnosis and treatment in the capital of Peru, where the best centers specialized in pediatric cancer treatment are located, and that every day they have been learning about how to survive all the adversities that were presented to them throughout the process.

\section{DISCUSSION}

This is the first study that explores the experiences that parents from different regions of Peru had during the process of seeking care for their children with cancer in specialized hospitals in Lima; and that they managed to obtain the desired cancer care. In this process, they perceived different forms of treatment in hospitals and shelters; they highlight the constant concern for the health of their children, their family and financial problems, which even affect their selfcare. Findings that are consistent with studies conducted in rural families in India(4) and Australia(11).

These results show that families living in regions distant from specialized centers, during the treatment of children with cancer experience psychosocial and economic problems reported as financial toxicity that refer to two types: objective and subjective. The first refers to additional costs related to treatment, such as: medications, outpatient care and hospitalizations. The subjective is related to possible alterations in the well-being and quality of patient care ${ }^{(13)}$. 
These extra expenses related to cancer treatment are similar to physical toxicity, since the costs can impact the quality of life (QoL) of family members, especially those who lack economic resources, such as parents who participated in this study, which could prevent adherence to the care and the proposed therapy. In this sense, providing psycho-emotional and socioeconomic support to families who have a child with cancer could be key to increasing the success of treatment $t^{(14)}$.

The negative attitudes of health personnel towards some parents during the process of access to health services of children with cancer, declared by the participants of this study, was also reported by a study carried out in India ${ }^{(4)}$ where they also point out that the inadequate treatment of health personnel affects the parents psychologically. Even more so if it is taken into account that due to the long journey, they sometimes do not report their concerns to health personnel for fear ${ }^{(11)}$ that increases suffering from a disease considered serious and culturally associated with inevitable death.

The causes that could be associated with negative attitudes towards parents, would be related to the lack of information of the administrative staff that these parents with their children come from distant areas and also due to the rigid rules that in many cases do not consider the situation that parents are going through violating their lifestyle. The challenge for the healthcare team throughout the disease and recovery process is to guarantee a favorable experience of: love, relief, serenity and joy; where health professionals, including the nurse, provide humanized care, trust, understanding and support to family members.

Another relevant aspect expressed by the parents was the need to be informed about aspects related to the disease such as diagnostic methods, treatment options, prognosis, symptoms, causes and long-term consequences; they also reported that this need generated uncertainty and anxiety. Considering that the lack of knowledge about the disease, symptoms and complications during treatment represents a difficulty for mothers to participate in the care of the child(15). The education provided to parents of children with cancer about the disease and social support networks could help reduce psycho-emotional problems and strengthen child care, but not only in specialized hospitals but also from health facilities from their region of origin; in this sense, the strengthening of the referral systems between the hospitals in their place of origin and the hospitals that receive them in Lima becomes relevant, to guarantee adequate care for the children and thus the parents would feel safer and more confident about the treatment of their children.

The statements of mothers show changes in their activities of daily life, they are forced to delegate the care of their minor children to other members of their family in their place of origin, they abandoned their studies and job. Similar experiences were reported by studies conducted in Brazil ${ }^{(9,15)}$ and Turkey ${ }^{(14)}$. In addition, it has been reported that the change of residence has a direct impact on the family routine in various psychosocial aspects, such as the abandonment of the social support network, of work and family ties ${ }^{(16)}$.

The diagnosis of cancer in a child disturbs the entire functional balance of the family and has negative effects on all its members. To maintain the balance of the different members of the family, parents need to adapt to new demands in their daily routine, which implies changes in behavior and redefinition of roles. The impact generates the need in the family to develop new skills and tasks, which interfere in their daily lives, personally, emotionally, socially, family and financially ${ }^{(17)}$.

On the other hand, financial toxicity, like other types of adverse events, can cause damage in different spheres of the patient's and family's lives, whether physical, psychological and also in the family routine ${ }^{(18)}$. With the increase in costs due to diagnosis, treatment, and possibly a decrease in income, the patient is unable to fully pay for the treatment. To do this, he/she has to reduce personal expenses and family activities, altering his/her family habits.

Women, due to multiple social and cultural aspects, have the responsibility to promote, care for and support the sick child, their other children and also the family. This condition is perceived, especially in Latin countries, where the mother plays several roles and is expected to develop competence in the care of the sick child ${ }^{(19)}$. A fact that was also observed in this study, reflected in the fact that most of the interviewees were mothers (14 of the 18 interviewees) who remained hospitalized with their children. In other studies, they also reported a higher prevalence of female caregivers ${ }^{(10,16)}$, this would reflect the fact that women historically assume the role of family caregiver, mainly of children.

The statements of parents showed the neglect of their self-care by prioritizing the needs of their children, generated by the costs of treatment and the purchase of food for them during hospitalization. On the contrary, in a study carried out with families in rural areas who had adults with cancer, it was reported that caregivers looked for alternatives to take care of themselves, distract themselves and keep busy with other activities ${ }^{(20)}$. This represents that the carelessness in the self-care of the caregiver of people with cancer is observed mainly when the affected person is a child. It is important to consider that the cancer treatment of the child generates great changes in the family dynamics and requires 
the caregiver to adopt a new routine, leaving their affective circle and their social relationships in the background ${ }^{(17)}$. The impacts of financial toxicity are accompanied by feelings of depression, anxiety and, consequently, a decrease in Qo $L^{(13)}$.

One of the problems reported by parents was the accommodation, especially of those who did not access the shelters as they did not have the information on these foster homes to which they could go, due to lack of adequate coordination of the administrative staff of the hospital of origin with the staff of the treating hospital in Lima. Coupled with scarce resources to pay for a hotel room, they were forced to sleep in the hospital facilities and did not have access to hygienic services due to the lack of financial resources to cover these expenses. Likewise, it has been reported that the main barrier faced by parents to be able to stay during the diagnosis and treatment when arriving at the hospital is finding accommodation; therefore, caregivers remain in metro stations and homeless shelters ${ }^{(4)}$.

Some parents who were admitted to the shelters reported having had positive experiences during their stay; however, others said they had been mistreated and little understood. The difficulties faced by families in shelters was also reported by a study carried out in Brazil, which pointed out problems with the distribution of rooms according to sex, discomfort, fatigue and physical exhaustion ${ }^{(2)}$. In this sense, accessing a shelter generates a series of experiences that can be contradictory, but represent an opportunity, especially for families with limited economic resources, facing the need to obtain accommodation because they are far from their home.

The parents also mentioned that to cover the expenses required for their stay in Lima, which is considered an expensive city in Peru, they had previously to provide their own resources, carry out activities to generate income and receive support from their relatives, in some cases selling their properties. A result that coincides with a study that reported that informal support came mainly from their family and often required negotiation, and this support was not perceived as a feeling of burden but rather a concern ${ }^{(11)}$. It is important to consider that the family of the child with cancer will necessarily need the support of the extended family, which is common in the Peruvian reality, either to take care of the child or as a financial resource.

Although in Peru there is a dynamic network for the referral and care of children with cancer to specialized health establishments that promotes adequate communication between the hospital network and social assistance to help these families; the statement of some parents shows that there is no proper coordination between the administrative staff of the hospitals in their region of origin with the social assistance of the Lima hospitals, so that many parents and children do not receive the benefits to which they are entitled , such as the use of shelters and help with the expenses they must make for the purchase of certain medicines that are not available in hospitals in Lima. Faced with these needs, the social support network plays an important role in these families, to reorganize and direct resources to provide care for the child with cancer and the remaining members of the family ${ }^{(16)}$. The health personnel, both the Social Service and the nurse must identify the situation of these parents who come to Lima with their children with cancer, according to the socioeconomic factors that make these families more vulnerable to the disease, they must coordinate and provide guidance on the support systems they can access, in this way base their interventions to help them and accompany them in the adaptation process ${ }^{(19)}$ thus improving the QoL of parents and their children.

\section{FINAL CONSIDERATIONS}

Parents seeking treatment for their children in an unknown city received help and support; but they also observed unfavorable attitudes from health personnel. In this "way of the cross" they adopted survival strategies, the majority who were informed, accessed shelters, where they received support, although they had to comply with strict rules and overcome discomfort. Some parents did not have the necessary information which made the experience more traumatic for them and their children with cancer.

They experienced neglect of their self-care, separation from their other children, loss of job, and dropping out of their studies. In addition, they had to assume the living expenses in the capital and the purchase of supplies and laboratory tests that the hospital did not have; that in some cases they were covered with the solidarity support of other relatives and friends, in extreme cases they sold their land or houses, or they got into debt.

One of the limitations of the study was that during the interview with the parents at the hospital, they probably did not disclose all their experiences for fear that their statements could interfere with the care process, even though the research team before starting the interview explained how they would ensure the confidentiality of the information. Another limitation of the study is related to the realization of focus groups in shelters, as they are considered places that could provide facilities for their execution, since access was mainly to the parents who were beneficiaries of this type of support.

The study will contribute to the Nursing practice in relation to the care of children with cancer and their family 
members; because it reveals the difficult situations faced by these families who come from distant places to Lima for the oncological treatment of their children and will allow to support the implementation of socioeconomic support strategies that favor a more empathetic, warm, and understanding approach towards parents to guide them to find solutions to their problems. In addition, the findings of the study will serve to reorient hospital policies, especially to carry out proper coordination between the hospital of origin and the hospital that provides specialized care in Lima to ensure timely diagnosis and treatment of children with cancer and guarantee the satisfaction of the basic needs of the parents, avoiding financial toxicity that is the cause of anxiety and stress, thereby improving the QoL of the parent-child pair undergoing cancer treatment.

\section{REFERENCES}

1. WardZJ, Yeh JM, Bhakta N, Frazier AL, Atun R. Estimating the total incidence of global childhood cancer: a simulation-based analysis. Lancet Oncol. 2019;20(4):483-93. doi: http://doi.org/10.1016/S1470-2045(18)30909-4

2. World Health Organization. Childhood cancer [Internet].Geneva: World Health Organization ; 2021 [cited 2020 Jul 21]. Available from: https://www.who.int/ news-room/fact-sheets/detail/cancer-in-children

3. Carriere R, Adam R, Fielding S, Barlas R, Ong Y, Murchie P. Rural dwellers are less likely to survive cancer - an international review and metaanalysis. Health Place. 2018:53:219-27. doi: https://doi.org/10.1016/j. healthplace.2018.08.010

4. Faruqui $N$, Joshi R, Martiniuk A, Lowe J, Arora R, Anis H, et al. A health care labyrinth: perspectives of caregivers on the journey to accessing timely cancer diagnosis and treatment for children in India. BMC Public Health. 2019;19:1613. doi: https://doi.org/10.1186/s12889-019-7911-x

5. Vasquez L, Diaz R, Chavez S, Tarrillo F, Maza I, Hernandez E, et al. Factors associated with abandonment of therapy by children diagnosed with solid tumors in Peru. Pediatr Blood Cancer. 2018;65(6):e27007. doi: https://doi. org/10.1002/pbc.27007

6. Ministerio de Salud, Centro Nacional de Epidemiología, Prevención y Control de Enfermedades. Análisis de la situación del cáncer en el Perú, 2018 [Internet]. Lima; 2020 [cited 2021 Mar 03]. Available from: https://www.dge.gob.pe/epipublic/ uploads/asis/asis_2020.pdf

7. Levesque JF, Harris MF, Russell G. Patient-centred access to health care: conceptualising access at the interface of health systems and populations. Int J Equity Health. 2013;12:18. doi: https://doi.org/10.1186/1475-9276-12-18
8. Renner LA, McGill D. Exploring factors influencing health-seeking decisions and retention in childhood cancer treatment programmes: perspectives of parents in Ghana. Ghana Med J. 2016;50(3):149-56. doi: https://doi.org/10.4314/ gmj.v50i3.6

9. Figueiredo dos Santos A, Sousa Guedes M, Cavalcante Tavares R, Brandão da Silva JM, Brandão Neto W, Bispo de Santana J, et al. Vivencias de madres con niños internos con diagnóstico de cáncer. Enferm Actual Costa Rica. 2018 [cited 2020 Jun 21];(34):38-52. Available from: https://www.scielo.sa.cr/pdf/enfermeria/ n34/1409-4568-enfermeria-34-38.pdf

10. Marques $G$. The family of the child with cancer: socioeconomic needs. Rev Gaúcha Enferm. 2017;38(4):e2016-0078. doi: https://doi. org/10.1590/1983-1447.2017.04.2016-0078

11. Coyne E, Frommolt V, Salehi A. The experience and challenges of rural persons with cancer and their families. Collegian. 2019;26(6):P609-14. doi: https://doi. org/10.1016/j.colegn.2019.10.002

12. Minayo MCS. La artesanía de la investigación cualitativa. Buenos Aires: Lugar Editora; 2009.

13. Nogueira LA, Machado CAM, Marques ACB, Kalinke LP. Implications of financial toxicity in the lives of cancer patients: a reflection. Rev Gaúcha Enferm. 2021;42:e20200095. doi: https://doi.org/10.1590/1983-1447.2021.20200095

14. Bozkurt C, Uğurlu Z, Tanyildiz HG, Yeşil \$̧, Kiraz H, Toprak \$, et al. Economic and psychosocial problems experienced by pediatric with cancer patients and their families during the treatment and follow-up process. Turk Pediatri Ars. 2019;54(1):35-9. doi: https://doi.org/10.14744\%2FTurkPediatriArs.2019.11129

15. Zafar SY, Peppercorn JM, Schrag D, Taylor DH, Goetzinger AM, Zhong X, Abernethy AP.The financial toxicity of cancer treatment: a pilot study assessing out-of-pocket expenses and the insured cancer patient's experience. Oncologist. 2013;18(4):38190. doi: https://doi.org/10.1634/theoncologist.2012-0279

16. Costa MADJ, Agra G, Santos CCB, Oliveira CDB, Freire MEM, Costa $M M L$. Experiences of the mothers of children with cancer in palliative care. J Nurs UFPE online. 2018;12(5):1355-64. doi: https://doi. org/10.5205/1981-8963-v12i5a235877p1355-1364-2018

17. Arruda-Colli MNF, Lima RAG, Perina EM, Santos MA. Child cancer recurrence: a study about the mother's experience. Psicol USP. 2016;27(2):307-14. doi:https:// doi.org/10.1590/0103-656420140078

18. Oliveira MR, Justa RMDE, Munguba MCS, Albuquerque LS, Diógenes MAR, Verde SMML. Câncer infantil: percepções de cuidadoras sobre alimentação, dinâmica familiar e emocional. Rev Bras Promoç Saúde. 2015 [cited 2020 Jun 15];28(4):5607. Available from: https://www.redalyc.org/articulo.oa?id=40846584012

19. Vieira AC, Cunha MLR. My role and responsibility: mothers' perspectives on overload in caring for children with cancer. Rev Esc Enferm USP. 2020;54: e03540. doi: http://doi.org/10.1590/s1980-220x2018034603540

20. Girardon-Perlini NMO, Van der Sand ICP, Beuter M, Rosa BVC. The experience of rural families who remain in halfway houses during cancer treatment. Rev Gaúcha Enferm. 2017; 38(1):e64093. doi: http://doi.org/10.1590/1983-1447.2017.01.64093 


\section{- Authorship contribution:}

Conceptualization: Gladys Carmela Santos Falcón,

Roberto Zegarra Chapoñan e Jhon Alex Zeladita

Huaman.

Data curation: Gladys Carmela Santos Falcón e Lili Ana

Ordoñez Espinoza.

Formal analysis: Gladys Carmela Santos Falcón e Jhon

Alex Zeladita Huaman.

Investigation: Gladys Carmela Santos Falcón e María del

Carmen Velandres Siles.

Methodology: María del Carmen Velandres Siles e

Roberto Zegarra Chapoñan.

Project administration: Jhon Alex Zeladita Huaman.

Resources: Lili Ana Ordoñez Espinoza e María del

Carmen Velandres Siles.

Supervision: Lili Ana Ordoñez Espinoza.

Validation: Gladys Carmela Santos Falcón e Jhon Alex

Zeladita Huaman.

Visualization: Roberto Zegarra Chapoñan.

Writing-original draft: Gladys Carmela Santos Falcón e

Jhon Alex Zeladita Huaman.

Writing-review \& editing: Gladys Carmela Santos Falcón,

Lili Ana Ordoñez Espinoza, María del Carmen Velandres

Siles, Roberto Zegarra Chapoñan e Jhon Alex Zeladita

Huaman.

The authors declare that there is no conflict of interest.

\section{- Corresponding author:}

Jhon Alex Zeladita Huaman

E-mail:jhon.zeladita@unmsm.edu.pe

\section{Editor-in-chief:}

Maria da Graça Oliveira Crossetti 